\title{
A survey of the tuberculosis physician workforce in the country of Georgia
}

\author{
D. S. Graciaa ${ }^{\star}$, M. Machaidze ${ }^{\# \dagger}$, M. Kipiani ${ }^{\# \ddagger}$, M. Buziashvili $^{\ddagger}$, K. Barbakadze ${ }^{\ddagger}$, Z. Avaliani ${ }^{\ddagger}$, \\ and R. R. Kempker§ \\ * Department of Medicine and Department of Family and Preventive Medicine, Emory University \\ School of Medicine, Atlanta, Georgia \\ † Division of Infectious Diseases, New York University School of Medicine, New York, New York, \\ USA \\ ‡ National Center for Tuberculosis and Lung Diseases, Tbilisi, Georgia \\ $\S$ Division of Infectious Diseases, Department of Medicine, Emory University School of Medicine, \\ Atlanta, Georgia, USA \\ \# These authors contributed equally to this work.
}

\section{SUMMARY}

SETTING: A well-trained and sufficient tuberculosis (TB) workforce is essential for disease control, especially in an era of newly implemented diagnostics and medications. However, there are few reports on the status of the TB workforce in many endemic countries.

OBJECTIVE : To evaluate the demographics, salary, career satisfaction, and attitudes towards the field of TB among the physician TB workforce in the country of Georgia.

DESIGN: A cross-sectional study of physicians in the current Georgian National TB Programme (NTP) using an anonymous 31-item questionnaire.

RESULTS: Among 184 NTP physicians countrywide, 142 (77\%) were contacted and 138 (75\%) completed questionnaires. The median age was 56 years (interquartile range 50-64); most (81\%) were female. The monthly salary from TB work was JSD205 for 50\% of respondents. Nearly half $(47 \%)$ received an additional salary from another source. Many physicians $(65 \%)$ indicated that they were satisfied with their work, but over half $(55 \%)$ were unsatisfied with reimbursement. While most physicians (78\%) were concerned about the lack of interest in TB, only $36 \%$ would recommend a career in TB care.

CONCLUSION: While the current TB workforce in Georgia finds their work fulfilling, an ageing workforce, low salaries and perceived lack of interest in the field are a matter of concern for future TB control.

Correspondence to: Daniel S Graciaa, Division of Infectious Diseases, Department of Medicine, Emory University School of Medicine, 49 Jesse Hill Jr Dr SE, Atlanta, GA 30303, USA. dsgraci@emory.edu.

Conflicts of interest: none declared. 


\section{RÉSUMÉ}

Une force de travail suffisante et bien formée pour la tuberculose (TB) est essentielle à la lutte contre la maladie, surtout a` une période de méthodes de diagnostic et de médicaments nouvellement mis en œuvre. Il y a cependant de rares rapports relatifs au statut de la main d'œuvre de la TB dans de nombreux pays d'endémie.

Evaluer la démographie, le salaire, la satisfaction professionnelle et les attitudes vis-à-vis du domaine de la TB parmi les médecins travaillant dans la TB en Géorgie.

Etude transversale relative aux médecins du Programme National TB (PNT) actuel grâce à un questionnaire anonyme de 31 items.

Parmi 184 médecins du PNT dans tout le pays, 142 (77\%) ont été contactés et 138 (75\%) ont rempli le questionnaire. L'âge médian a été de 56 ans (intervalle interquartile 50-64) et la majorité (81\%) ont été des femmes. Le salaire mensuel lié au travail relatif à la TB a été de 6205 \$US pour $50 \%$ des répondants. Presque la moitié $(47 \%)$ reçoit un salaire supplémentaire d'une autre source. De nombreux médecins (65\%) ont affirmé qu'ils étaient satisfaits de leur travail, mais plus de la moitié $(55 \%)$ étaient insatisfaits du remboursement. Si la plupart des médecins $(78 \%)$ ont été préoccupés par le manque d'intérêt vis-à-vis de la TB, seulement 36\% recommanderaient une carriére dans le domaine de la TB.

Si la force de travail actuelle de la TB en Géorgie trouve sa tâche gratifiante, l'âge avancé de ces professionnels, les salaires bas et le manque d'intérêt perc, u vis-à-vis de la TB sont préoccupants pour l'avenir de la lutte contre la TB.

\section{RESUMEN}

Contar con un equipo de trabajo en tuberculosis (TB) bien capacitado es esencial en el control de la enfermedad, sobre todo en una época de introducción de nuevos medios diagnósticos y nuevos fármacos. Sin embargo, existen pocos informes sobre la situación del personal que trabaja en TB en muchos países endémicos.

OBJETIVO: Evaluar las características demográficas, los sueldos, la satisfacción profesional y las actitudes hacia el campo de la TB en el personal médico que se ocupa de la TB en el país de Georgia.

Fue este un estudio transversal del personal médico vinculado en la actualidad con el Programa Nacional contra la Tuberculosis (PNT) con un cuestionario anónimo de 31 elementos.

De los 184 médicos del PNT en todo el país, se contactaron 142 (77\%) y 138 completaron los cuestionarios (75\%). La mediana de la edad fue 56 años (intervalo intercuartil 50-64) y la mayoría era de sexo femenino (81\%). El sueldo mensual por el trabajo en TB era de 205 USD en el 50\% de quienes respondieron. Cerca de la mitad (47\%) recibía un sueldo complementario de otra fuente. La mayor parte del personal médico (65\%) afirmó su satisfacción con el trabajo, pero más de la mitad (55\%) estaba insatisfecho con el pago. La mayoría (78\%) se preocupaba por la falta de interés en la TB, pero solo el 36\% recomendaría ejercer en este campo.

En la actualidad, los profesionales que trabajan en TB en Georgia consideran su trabajo gratificante, pero un personal que envejece, los bajos sueldos y la percepción de una falta de interés en este campo de trabajo son motivos de preocupación para el futuro del control de la TB. 


\section{Keywords}

health care workers; TB; training; job satisfaction

TUBERCULOSIS (TB) REMAINS A MAJOR global health problem, with an estimated 10.4 million incident cases of TB worldwide and 1.7 million TB-related deaths in $2016 .{ }^{1}$ There are several barriers to ending the TB epidemic, including challenges in prevention, case detection andtreatment. ${ }^{2}$ Importantly, to achieve progress in these areas, the availability and effectiveness of an ample TB workforce is required. ${ }^{3}$

The World Health Organization declared in 2003 that a 'workforce crisis' was a significant obstacle to TB control, and has continued to emphasise the importance of human resources for health. ${ }^{4-6}$ With the emergence of difficult-to-treat drug-resistant disease and implementation of new diagnostics and drugs, a sufficient TB workforce is as important as ever to utilise these novel tools to make progress against the epidemic.

Our study was conducted in the country of Georgia, which has experienced recent successes in TB control: the estimated overall incidence rate decreased from 127 per 10000 population in 2010 to 116 in 2013 and finally to 92 in $2016 .{ }^{7}$ For drug-susceptible TB, the treatment success rate is $84 \%$ and hospital bed days per patient have decreased by $38 \%$. An estimated $2.1 \%$ of all cases are co-infected with the human immunodeficiency virus (HIV). ${ }^{1}$ However, Georgia remains affected by high rates of multidrug-resistant TB (MDR-TB), including $11 \%$ among new cases and $31 \%$ among previously treated cases in $2016 .{ }^{1}$ Despite universal access to diagnosis and treatment of MDR-TB, case notification has not trended down, with 359 cases in 2010, 400 cases in 2013, and 319 cases in 2016; outcomes are less favourable than in similar settings, with a reported treatment success rate of $49 \%{ }^{7,8}$ The National TB Programme (NTP) provides treatment for all cases of TB in Georgia; human resource reports have suggested an aging workforce and revealed that no new physicians have joined the NTP in the last decade (Z Avaliani, personal communication). This has generated concerns about the next generation of TB physicians in Georgia.

To create solutions to such workforce challenges, it is important to understand the factors contributing to their development, as in recent studies investigating the sustainability of the care provider workforce for HIV and infectious diseases in the United States. ${ }^{9}, 10$ Previous reports on TB programmes in Georgia and other former Soviet countries have described workforce capacity, but have not focused on human factors. ${ }^{11-13}$ We conducted a study to investigate the demographics, compensation, career satisfaction and attitudes towards TB among current NTP physicians in Georgia. Our goal was that describing these contexts would provide data to inform development of a sustainable TB workforce in Georgia and in other countries with a similar problem.

\section{STUDY POPULATION AND METHODS}

\section{Study design/procedures}

We conducted a descriptive, cross-sectional study using an anonymous, 31-item selfadministered questionnaire in the Georgian language, with items developed based on 
published studies (see English version in the Appendix*). ${ }^{9,10}$ Data collected were age, sex, location of medical training, English proficiency, job and salary characteristics, research opportunities and training, and attitudes towards TB. Variables are listed in Tables 1 and 2.

A five-point Likert scale ranging from very satisfied/strongly agree to very unsatisfied/ strongly disagree was used to determine items on satisfaction and attitudes. The questionnaire was translated from English by a native Georgian speaker, then reviewed and edited for the local context by two additional native speakers. Due to time constraints, it was not field-tested.

All NTP physicians directly involved in TB patient care according to the NTP's human resources records were eligible to participate; physicians serving in solely administrative or research roles were excluded. Questionnaires were distributed on paper or via e-mail at the National Centre for Tuberculosis and Lung Disease (NCTLD) in Tbilisi, Georgia, and satellite facilities in all 11 regions of Georgia during March 2017. Oral consent was obtained and consent to participate was implied if the participants completed and returned the questionnaire. Completed questionnaires were collected at the distribution site or returned to study staff via NTP courier or e-mail within 3 weeks of distribution. No incentives were provided for participation.

Approval of the study protocol was obtained from the Institutional Review Board at Emory University, Atlanta, GA, USA, and the Ethics Committee of the NCTLD, Tbilisi.

\section{Setting}

Physicians caring for patients with TB in Georgia must complete at least 3 years of residency training after completing their undergraduate education; they include TB clinicians (specialised in the medical management of TB) and TB surgeons (specialised in the surgical management of TB). ${ }^{14}$ Specialisation in TB (phthisiatry) was previously separate from pulmonology, but these fields were combined into a single specialty in 2014.

The majority of Georgians participate in state-funded health insurance; approximately $10 \%$ use private insurance. ${ }^{15}$ The national mean monthly salary is approximately 380 US dollars (USD) for the total workforce and USD395 for the health services workforce; providers in the public sector are paid less than those in the private sector. ${ }^{16}$

\section{Statistical methods}

Descriptive analysis was completed using SAS v9.4 (Statistical Analysis System, Cary, NC, USA). Differences between groups were assessed using Student's $t$-test for continuous variables and $\chi^{2}$ test for categorical variables. Likert scale items were collapsed into a binary outcome for an exploratory analysis of associations between responses.

\footnotetext{
* The appendix is available in the online version of this article, at http://www.ingentaconnect.com/content/iuatld/ijtld/ 2018/00000022/00000011/art00008
} 


\section{RESULTS}

Among 184 NTP physicians, 142 (77\%) were contacted and 138 (75\%) completed the questionnaire: 131 questionnaires were completed on paper and 7 via e-mail. Of the 42 physicians not contacted due to absence from work on multiple staff visits to sites or unreturned e-mail, 15 worked in the capital, Tbilisi, with the remainder working in other regions of Georgia.

The median age of the 138 participants was 56 years (interquartile range [IQR] 50-64). Physicians from all 11 regions were included; 56 (40.6\%) worked in Tbilisi. Nearly all participants $(n=122,88.4 \%)$ were TB clinicians, with the remainder being TB surgeons. The median number of years of service with the NTP was 22 (IQR 17.5-30). A minority were involved in research $(n=25,18.1 \%)$, clinical supervision or teaching medical students $(n=11,8.0 \%)($ Table 1$)$.

The self-reported monthly salary from the NTP was USD205 for $72(52.1 \%)$ respondents and >USD360 for 17 (12.3\%). Nearly half reported receiving additional salaries from either research activities $(n=20,14.5 \%)$ or other sources $(n=46,33.3 \%)$, with a median payment of USD200 (IQR 110-322) from these supplemental salaries. Half $(n=69)$ reported receiving a pay rise in the previous 5 years (Table 1 ).

Table 2 presents questionnaire responses regarding career satisfaction and attitudes towards TB. The majority of participants reported they were either 'satisfied' or 'very satisfied' with their personal fulfilment from work in TB $(n=87,63 \%)$, work environment $(n=115$, $83.3 \%)$, support from the NTP ( $n=92,66.7 \%)$, training on advances in TB management ( $n$ $=115,83.3 \%)$, and availability of TB medications $(n=133,96.4 \%)$. A minority were satisfied with current reimbursement ( $n=19,13.8 \%)$, opportunities to be involved in research $(n=44,31.9 \%)$, and availability of medications to treat comorbidities other than HIV $(n=64,46.4 \%)$. Only $11(8.0 \%)$ agreed that reimbursement for a TB physician was competitive compared with other medical specialties. Of those satisfied with their reimbursement, $10(52.6 \%)$ reported a salary in the highest category and none in the lowest category. Slightly more than half of the participants $(n=75,54.3 \%)$ indicated they would choose TB if given the opportunity to select their medical specialty again. The majority agreed that there was a lack of interest in the field of TB among current medical students in Georgia $(n=106,76.8 \%)$ and that they were concerned about the number of young physicians entering the field of TB $(n=108,78.3 \%)$. However, only 50 physicians $(36.2 \%)$ agreed that they would recommend working in TB to graduating medical students. Nearly all agreed that while TB remains a major public health problem in Georgia, TB control had improved in the last 5 years $(n=116,84.1 \%)$ (Table 2).

A contingency table of physicians reporting personal fulfilment from work in TB and willingness to recommend the field to medical students found a statistically significant association $\left(\chi^{2}=17.74, P<0.001\right)$ (Table 3). Personal fulfilment from work in TB and willingness to choose the field again if given the opportunity were associated $\left(\chi^{2}=20.27, P\right.$ $<0.001)$. However, there were no associations between the reported monthly salary from the 
NTP.USD200 and personal fulfilment $\left(\chi^{2}=0.24, P=0.6233\right.$ ) or willingness to choose the field again $\left(\chi^{2}=0.002, P=0.9644\right)$.

\section{DISCUSSION}

Reassuringly, our survey of NTP physicians in Georgia found a high rate of job satisfaction among current physicians, but it also led to some sobering findings. The results confirmed anecdotal accounts that the TB workforce in Georgia is ageing, with most current physicians (75\%) aged over 50 years. This, along with findings of low salaries, a high rate of salary dissatisfaction, and concern about the lack of young physicians interested in TB, is worrisome. While TB incidence has been declining in Georgia, rates of difficult-to-treat MDR-TB and extensively drug-resistant TB remain high, requiring skilled clinicians for optimal management of TB. ${ }^{1}$ Understanding the current workforce will help guide workforce development strategies.

Our findings indicate that TB physicians are satisfied overall and with several specific aspects of their work, including their work environment, relationships with colleagues, support from the NTP, training and availability of TB medications. These findings suggest that the current TB workforce is likely appropriately trained for and supported in their career. This conclusion is further evidenced by recent successes in TB in Georgia, including reducing TB incidence and becoming the first low/middle-income country with universal access to drug susceptibility testing and treatment, among others. ${ }^{1}$ Ensuring that these successes continue requires planning for the future workforce.

Worrying features of the current workforce that must be addressed are an ageing population of physicians and a lack of identified replacements, as well as low compensation, with nearly half of the physicians surveyed supplementing their income with other activities. The self-reported monthly salary of $\mathrm{JUSD} 205$ for over half of respondents is considerably lower than the mean monthly salary for both the total workforce (USD380) and the health services sector (USD395) ${ }^{16}$ Improved compensation for TB physicians would make salaries more competitive with those of comparable jobs, and would be consistent with the United Nations Sustainable Development Goal 3C. ${ }^{17}$ The self-reported salary from NTP activities was not associated with reported satisfaction or willingness to choose the field of TB again if given the opportunity among current physicians. Given that no new physicians have joined the NTP in over 10 years, it is not surprising that over three quarters of the surveyed workforce is concerned about the number of young physicians entering their specialisation. In addition, the complexities of TB diagnostics and the management of drug-resistant cases with medications that are associated with significant and frequent adverse events necessitate welltrained and experienced clinicians. ${ }^{18,19}$ Taken together, these realities suggest that the future TB physician workforce may be inadequate, and that increasing compensation alone may not increase recruitment.

Planning for and developing an adequate and sustainable TB workforce will likely require a multifaceted approach. Although there has been significant investment in TB diagnostics and treatment, little investment has been directed towards the workforce, and the research and development funding currently in place is likely insufficient. ${ }^{20,21}$ Increasing community- 
based care and task shifting could reduce the strain on health care facilities and providers. 19,22

Physician satisfaction is important for a sustainable workforce as well as patient satisfaction with care. ${ }^{23}$ We found an association between personal fulfilment from working in TB and willingness to choose this specialisation again or recommend it to medical students. Career satisfaction is multifactorial, with reimbursement, administrative burden, diversity of work activities and availability of ongoing training all contributing. ${ }^{9,24}$ TB care providers also face the workplace hazard of nosocomial transmission of infection, including MDR-TB, from patients. ${ }^{25,26}$ Various mechanisms have been used to direct external human resources investments to health care workers, but ensuring the sustainability of compensation after transition to domestic funding will be crucial. ${ }^{27}$

Expanding research and clinical opportunities within TB may allow the development of a clinician-scientist track in Georgia and increase the appeal of the specialty to current residents. The recent combination of phthisiatry and pulmonology aligns with a peoplecentred model of TB care. ${ }^{22}$ There are currently three residents training in phthisiatrypulmonology at the NCTLD. This increase is attributed in large part to an expansion of research activity and therefore opportunities at the NCTLD, including ongoing clinical trials of new anti-tuberculosis drugs, and a National Institutes of Health Fogarty International Center Global Infectious Diseases (Bethesda, MD, USA) programme. ${ }^{28}$ While we did not find an association between involvement in research and overall satisfaction, only $18 \%$ of respondents reported being involved in research activities. Broadening the scope of practice of NTP physicians to include more general pulmonary disease could facilitate a greater variety of career options, as has been suggested for the specialisation of infectious diseases in the United States. ${ }^{29}$ This strategy is consistent with calls to better integrate programmes for TB control and non-communicable diseases, including chronic lung disease. ${ }^{30}$ The medical training pathway is essential to the supply of the physician workforce and, according to our data, only $8 \%$ of respondents provided clinical supervision or teaching to medical students. This limits exposure to the field of TB and mentorship from current clinicians for future physicians, factors that have been identified as influential for career choice. ${ }^{31}$

Our study provides an overview of physician workforce characteristics in Georgia, which are likely similar in other countries in the region with comparable medical training systems. The size of the country and the NTP allowed all NTP physicians to be eligible for inclusion in the study, which resulted in a high participation rate but may limit generalisability to larger countries. Physicians who did not return the questionnaire may have introduced selection bias. Surveying only NTP employees may have prevented our capturing the diversity of TB providers and practice in Georgia (e.g., excluding private clinics), and including only physicians limited insight into the breadth of the TB workforce (e.g., nurses and other health workers). The present study was also limited by the use of a self-reported questionnaire distributed in the workplace, which may have introduced a social desirability bias, although anonymity and the option to return the questionnaire later or via e-mail may have mitigated this effect. 32 
Future research directions include a similar study among medical students in Georgia to describe attitudes towards a career in TB care or research, and to identify the factors associated with choice of medical specialty. Surveying nurses involved in the NTP could identify ways to strengthen the workforce by expanding their role. Finally, a similar survey of TB physicians in a larger country using appropriate sampling methods could show if and how workforce characteristics and attitudes differ between populations.

\section{CONCLUSION}

In Georgia, the majority of physicians involved in TB are satisfied with their work but dissatisfied with compensation and concerned about the future of the TB workforce. While current NTP workforce support should continue, strategies such as integrating TB training and care with other specialties, continuing medical education, and sustainable salary support, as part of overall health systems strengthening, may enhance recruitment and retention of an adequate TB workforce.

\section{Acknowledgements}

This work was supported in part by the National Institutes of Health Fogarty International Center (Bethesda, MD; D43TW007124); National Institute of Allergy and Infectious Diseases (Bethesda; K23AI103044; R21AI122001); the Atlanta Clinical and Translational Science Institute (Atlanta, GA; UL1TR000454), and the Emory University Global Health Institute (Atlanta).

The authors thank all National Tuberculosis Program staff and the following individuals for their invaluable assistance with the project: M Davitashvili, Z Dgebuadze, T Endeladze, M Ghong-hadze, G Gonashvili, N Khuchua, S Kuchava, T Janelidze, K Mshvenieradze, and D Tsetskhladze. 
APPENDIX

HEALTH CARE WORKER SURVEY

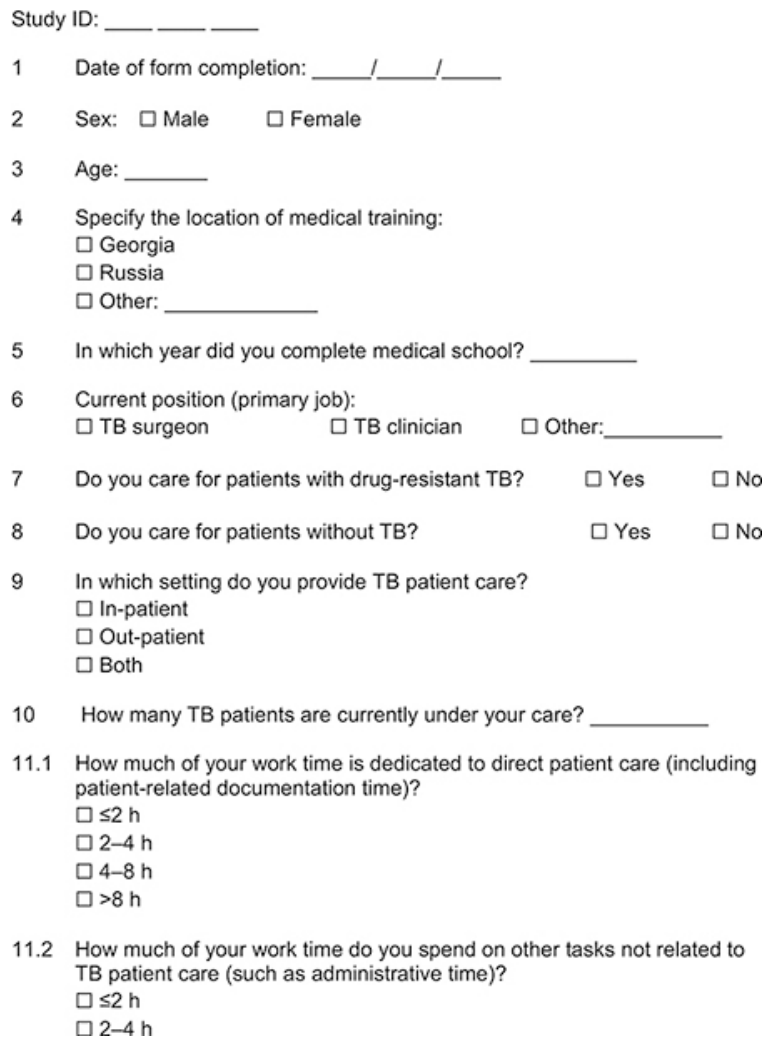

11.2 How much of your work time do you spend on other tasks not related to TB patient care (such as administrative time)?

$\square \leq 2 \mathrm{~h}$

$\square 2-4 h$ 
$4-8 \mathrm{~h}$

$\square>8 \mathrm{~h}$

Do you work at the NCTLD? $\square$ Yes $\square$ No

14

Do you work in the prison department? $\square$ Yes $\square$ No

$\square$ Kakheti

$\square$ Shida Kartli

$\square$ Kvemo Kartli

$\square$ Imereti

$\square$ Racha-Lechkhumi

$\square$ Guria

$\square$ Samegrelo/Zemo Svaneti

$\square$ Samckhe-Javakheti

$\square$ Adjara

$\square$ Tbilisi

16 Is the institution where you work public or private?

$$
\checkmark \text { Public } \quad \square \text { Private }
$$

17.1 Have you ever been treated for active TB? $\square$ Yes

17.2 What type of TB were you treated for? (mark all that apply)

$$
\square \text { drug-susceptible } \square \text { drug-resistant }
$$

18 Current monthly salary in Georgian lari* working for the National TB Programme (including VAT):

$\square<300$

$\square$ 300-500

$\square$ 500-700

$\square 700-900$

$\square>900$

19.1 Do you receive any salary from a source other than your work for the National TB Programme?

19.2 Average monthly additional salary from source outside the National TB Programme:

20 Have you received a pay rise in the last 5 years? $\square$ Yes $\square$ No

21 Do you plan to retire from your work in the next 5 years? $\square$ Yes $\square$ No

22 Are you currently involved in clinical research? $\square$ Yes (go to 22,1) $\quad$ No (go to 23)

22.1 Do you receive any salary support from research activities? $\square$ Yes $\quad$ No

22.2 Average monthly additional salary from research activities?

23 Do you speak fluent or intermediate English? QYes $\quad$ No

24 Can you read English? $\square$ Yes $\quad$ NNo

\begin{tabular}{|c|c|c|c|c|c|c|}
\hline & Question & $\begin{array}{l}\text { Very } \\
\text { satisfied } \\
\text { (1) }\end{array}$ & $\begin{array}{l}\text { Satisfied } \\
\text { (2) }\end{array}$ & $\begin{array}{l}\text { Neutral } \\
\text { (3) }\end{array}$ & $\begin{array}{l}\text { Unsatisfied } \\
\text { (4) }\end{array}$ & $\begin{array}{l}\text { Very } \\
\text { unsatisfied } \\
\text { (5) }\end{array}$ \\
\hline & \multicolumn{5}{|l|}{ Personal fulfilment from your work } & \\
\hline & \multirow{3}{*}{$\begin{array}{l}\text { Salary or reimbursement rates } \\
\text { Work schedule and/or on-call } \\
\text { responsibilities }\end{array}$} & 1 & $\begin{array}{l}2 \\
2\end{array}$ & $\begin{array}{l}3 \\
3\end{array}$ & 4 & $\begin{array}{l}5 \\
5\end{array}$ \\
\hline & & & & & & \\
\hline & & 1 & 2 & 3 & 4 & 5 \\
\hline \multirow{2}{*}{ d) } & providing care for & 1 & 2 & 3 & 4 & 5 \\
\hline & $\begin{array}{l}\text { available for documentation and } \\
\text { other administrative work }\end{array}$ & 1 & 2 & 3 & 4 & 5 \\
\hline 9) & $\begin{array}{l}\text { Work environment and relationship } \\
\text { with other colleagues }\end{array}$ & 1 & 2 & 3 & 4 & 5 \\
\hline \multirow{2}{*}{$\begin{array}{l}\text { g) } \\
\text { h) }\end{array}$} & $\begin{array}{l}\text { Adequate support from the National } \\
\text { TB Program at government level }\end{array}$ & 1 & 2 & 3 & 4 & 5 \\
\hline & $\begin{array}{l}\text { research } \\
\text { resties to o involved in }\end{array}$ & 1 & 2 & 3 & 4 & \\
\hline
\end{tabular}

25 Please indicate your level of satisfaction with the following areas of your

Int J Tuberc Lung Dis. Author manuscript; available in PMC 2019 May 01. 


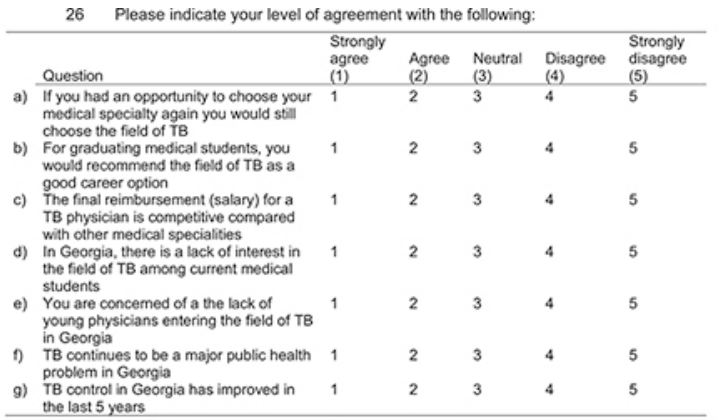

27. Do you provide any clinical supervision or teaching to medical students? $\square$ Yes $\square$ No

28 Patient care: please indicate your level of satisfaction regarding the

\begin{tabular}{|c|c|c|c|c|c|}
\hline Question & $\begin{array}{l}\text { Very } \\
\text { satisfled } \\
\text { (1) }\end{array}$ & $\begin{array}{l}\text { Satisfied } \\
\text { (2) }\end{array}$ & $\begin{array}{l}\text { Neutral } \\
\text { (3) }\end{array}$ & $\begin{array}{l}\text { Unsatisfled } \\
\text { (4) }\end{array}$ & $\begin{array}{l}\text { Very } \\
\text { unsatisfied } \\
\text { (5) }\end{array}$ \\
\hline \multicolumn{6}{|l|}{ Training/education } \\
\hline $\begin{array}{l}\text { a) Training on new advances in TB } \\
\text { management }\end{array}$ & 1 & 2 & 3 & 4 & 5 \\
\hline $\begin{array}{l}\text { b) Training on the use of new } T 8 \\
\text { drugs }\end{array}$ & 1 & 2 & 3 & 4 & 5 \\
\hline $\begin{array}{l}\text { c) Training on management of } \\
\text { adverse TB drug events }\end{array}$ & 1 & 2 & 3 & 4 & 5 \\
\hline $\begin{array}{l}\text { d) Training on the use and } \\
\text { interpretation of new TB diagnostic } \\
\text { tests }\end{array}$ & 1 & 2 & 3 & 4 & 5 \\
\hline $\begin{array}{l}\text { e) Available time to receive training on } \\
\text { TB management }\end{array}$ & 1 & 2 & 3 & 4 & 5 \\
\hline $\begin{array}{l}\text { f) Access to medical journals for up to } \\
\text { date information on TB } \\
\text { management }\end{array}$ & 1 & 2 & 3 & 4 & 5 \\
\hline $\begin{array}{l}\text { Resources for patient care } \\
\text { 9) Support and coverage from other } \\
\text { TB providers }\end{array}$ & 1 & 2 & 3 & 4 & 5 \\
\hline
\end{tabular}

$\begin{array}{llllll}\text { 9) Support and coverage from other } & 1 & 2 & 3 & 4\end{array}$

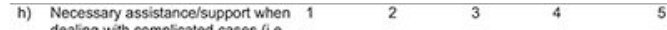
dealing with complicated cases (i.e.

multiple comorbicities)

consultation and rectists

Availability of HIV specialists assistance managing HIV-TB $c 0$ -

assistance managing HIV-TB co-
infected patients Availability of antituberculosis

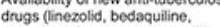

(inid) for drug resistont

Availability of drugs to ment

events resulting from use of anti-

o) Availability of dings to treat patient comorbidties (other than HIV, i.e.
diabetes, COPD, hypertension, etc.

Work place safety

p) Implementation of infection control

Availability of N95 respiratory

masks

Adequate ventiation at your

(acility to prevent TB

29 What is your main source of information on TB care and treatment?

- Georgia National Tuberculosis Guidelines

$\checkmark$ Internationalnational conferences

a In-country training

a Medical journ

$\square$ Websites with clinical information

Pharmaceutical representatives

口WHO documents

$\square$ Guest lectures by visiting professors

30 Which sources of information on TB care and treatment have you used in the past year? (mark all that apply)

Georgia National Tuberculosis Guidelines

Qintemationanatonal conterences

$\square$ In-country training

Int J Tuberc Lung Dis. Author manuscript; available in PMC 2019 May 01. 


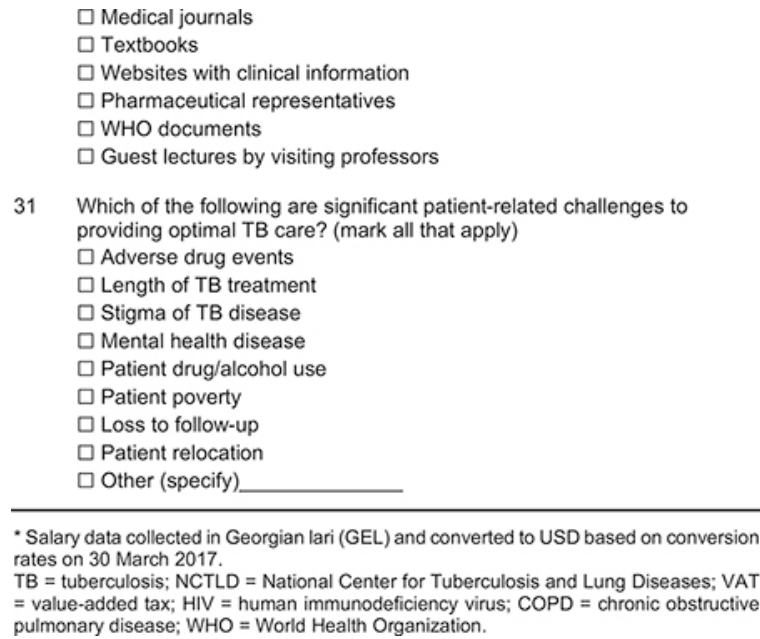

- Salary data collected in Georgian lari (GEL) and converted to USD based on conversion rates on 30 March 2017

TB $=$ tuberculosis; NCTLD $=$ National Center for Tuberculosis and Lung Diseases; VAT $=$ value-added tax; HIV $=$ human immunodeficiency virus; $\mathrm{COPD}=$ chronic obstructive pulmonary disease; $\mathrm{WHO}=$ World Health Organization.

\section{References}

1. World Health Organization. Global tuberculosis report, 2017. WHO/HTM/TB/2017.23 Geneva, Switzerland: WHO, 2017.

2. World Health Organization. The End TB Strategy. Geneva, Switzerland: WHO, 2014.

3. Cowan J, Greenberg Cowan J, et al. A qualitative assessment of challenges to tuberculosis management and prevention in Northern Ethiopia. Int J Tuberc Lung Dis 2013; 17: 1071-1075. [PubMed: 23735536]

4. World Health Organization. TB workforce crisis a major obstacle to treatment success. Geneva, Switzerland: WHO, 2003 http://www.who.int/mediacentre/news/releases/2003/pr74/en/ Accessed July 2018.

5. Figueroa-Munoz J, Palmer K, Poz MR, Blanc L, Bergstrom K, Raviglione M. The health workforce crisis in TB control: a report from high-burden countries. Hum Resour Health 2005; 3: 2. [PubMed: 15730555]

6. World Health Organization. Global strategy on human resources for health: workforce 2030. Geneva, Switzerland: WHO, 2016.

7. World Health Organization. Global tuberculosis database. Geneva, Switzerland: WHO, 2018 http:// www.who.int/tb/country/data/download/en/. Accessed July 2018.

8. Kempker RR, Kipiani M, Mirtskhulava V, Tukvadze N, Magee MJ, Blumberg HM. Acquired drug resistance in Mycobacterium tuberculosis and poor outcomes among patients with multidrugresistant tuberculosis. Emerg Infect Dis 2015; 21: 992-1001. [PubMed: 25993036]

9. Weiser J, Beer L, West BT, Duke CC, Gremel GW, Skarbinski J. Qualifications, demographics, satisfaction, and future capacity of the HIV care provider workforce in the United States, 20132014. Clin Infect Dis 2016; 63: 966-975. [PubMed: 27358352]

10. Bonura EM, Lee ES, Ramsey K, Armstrong WS. Factors influencing internal medicine resident choice of infectious diseases or other specialties: a national cross-sectional study. Clin Infect Dis 2016; 63: 155-163. [PubMed: 27126345]

11. Bonnet M, Sizaire V, Kebede Y, et al. Does one size fit all? Drug resistance and standard treatments: results of six tuberculosis programmes in former Soviet countries. Int J Tuberc Lung Dis 2005; 9: 1147-1154. [PubMed: 16229227]

12. Ulmasova DJ, Uzakova G, Tillyashayhov MN, et al. Multidrug-resistant tuberculosis in Uzbekistan: results of a nationwide survey, 2010 to 2011. Euro Surveill 2013; 18: 20609. [PubMed: 24176581]

13. World Health Organization Regional Office for Europe. Analysis of the epidemiological impact of tuberculosis in Georgia. Copenhagen, Denmark: WHO, 2015 http://www.euro.who.int/_data/ assets/pdf_file/0010/321949/Analysis-epidemiological-impact-TBC-Georgia.pdf?ua=1Accessed July 2018. 
14. Chanturidze T, Ugulava T, Durán A, Ensor T, Richardson E. Georgia: health system review. Copenhagen, Denmark: World Health Organization, 2009.

15. World Health Organization Regional Office for Europe. Georgia: highlights on health and wellbeing. Copenhagen, Denmark: WHO, 2017 http://www.euro.who.int/_data/assets/pdf_file/ 0004/351697/WHO_GEORGIA_HIGHLIGHTS_EN.pdf?ua=1 Accessed July 2018.

16. National Statistics Office of Georgia. Average monthly nominal earnings of employees by economic activity, 1998-2016. Tbilisi, Georgia: NSO, 2017 http://www.geostat.ge/index.php? action=page\&p_id=149\&lang=eng. Accessed July 2018.

17. United Nations Department of Economic and Social Affairs. Global indicator framework for the Sustainable Development Goals. New York, NY, USA: UN DESA, 2017 https://unstats.un.org/ sdgs/indicators/indicators-list/Accessed July 2018.

18. Wu S, Zhang Y, Sun F, et al. Adverse events associated with the treatment of multidrug-resistant tuberculosis: a systematic review and meta-analysis. Am J Ther 2016; 23: e521-530. [PubMed: 24284652]

19. Dheda K, Gumbo T, Maartens G, et al. The epidemiology, pathogenesis, transmission, diagnosis, and management of multidrug-resistant, extensively drug-resistant, and incurable tuberculosis. Lancet Respir Med 2017; 315 [Epub ahead of print].

20. Menzies NA, Gomez GB, Bozzani F, et al. Cost-effectiveness and resource implications of aggressive action on tuberculosis in China, India, and South Africa: a combined analysis of nine models. Lancet Glob Health 2016; 4: e816-e826. [PubMed: 27720689]

21. Frick M Funding for tuberculosis research-an urgent crisis of political will, human rights, and global solidarity. Int J Infect Dis 2017; 56: 21-24. [PubMed: 27919779]

22. World Health Organization Regional Office for Europe. A people-centred model of tuberculosis care. Copenhagen, Denmark: WHO, 2017 http://www.euro.who.int/_data/assets/pdf_file/ 0004/342373/TB_Content_WHO_PRO_eng_final.pdf?ua=1 Accessed July 2018.

23. Haas JS, Cook EF, Puopolo AL, Burstin HR, Cleary PD, Brennan T A. Is the professional satisfaction of general internists associated with patient satisfaction? J Gen Intern Med 2000; 15: 122-128. [PubMed: 10672116]

24. Kadri SS, Rhee C, Magda G, et al. Synergy, salary, and satisfaction: benefits of training in critical care medicine and infectious diseases gleaned from a national pilot survey of dually trained physicians. Clin Infect Dis 2016; 63: 868-875. [PubMed: 27358351]

25. Joshi R, Reingold AL, Menzies D, Pai M. Tuberculosis among health-care workers in low-and middle-income countries: a systematic review. PLOS Med 2006; 3: e494. [PubMed: 17194191]

26. Whitaker JA, Mirtskhulava V, Kipiani M, et al. Prevalence and incidence of latent tuberculosis infection in Georgian healthcare workers. PLOS ONE 2013; 8: e58202. [PubMed: 23536789]

27. Bowser D, Sparkes SP, Mitchell A, et al. Global Fund investments in human resources for health: innovation and missed opportunities for health systems strengthening. Health Policy Plan 2014; 29: 986-997. [PubMed: 24197405]

28. Kempker RR, Tukvadze N, Sthreshley L, Sharling L, et al. The impact of a Fogarty International Center-supported tuberculosis research training program in the country of Georgia. Am J Trop Med Hyg 2018; 98: 1069-1074. [PubMed: 29405100]

29. Walensky RP, Del Rio C, Armstrong WS. Charting the future of infectious disease:anticipating and addressing the supply and demand mismatch. Clin Infect Dis 2017; 64: 1299-1301. [PubMed: 28387806]

30. Harries AD, Ade S, Burney P, Hoa NB, Schluger NW, Castro JL. Successfully treated but not fit for purpose: paying attention to chronic lung impairment after TB treatment. Int J Tuberc Lung Dis 2016; 20: 1010-1014. [PubMed: 27393532]

31. Bonura EM, Armstrong WS. Increasing subspecialization in the field of infectious diseases: evaluating challenges and strategies to move forward. J Infect Dis 2017; 216 (Suppl 5): S594S599. [PubMed: 28938043]

32. Althubaiti A Information bias in health research: definition, pitfalls, and adjustment methods. $\mathbf{J}$ Multidiscip Healthc 2016; 9: 211-217. [PubMed: 27217764] 


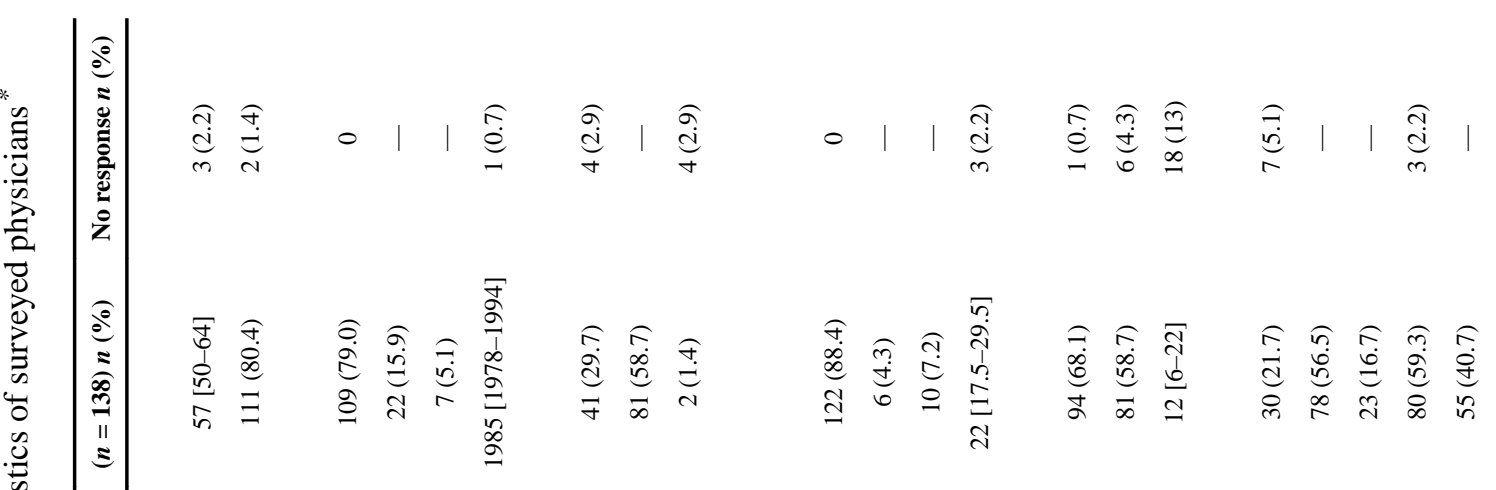

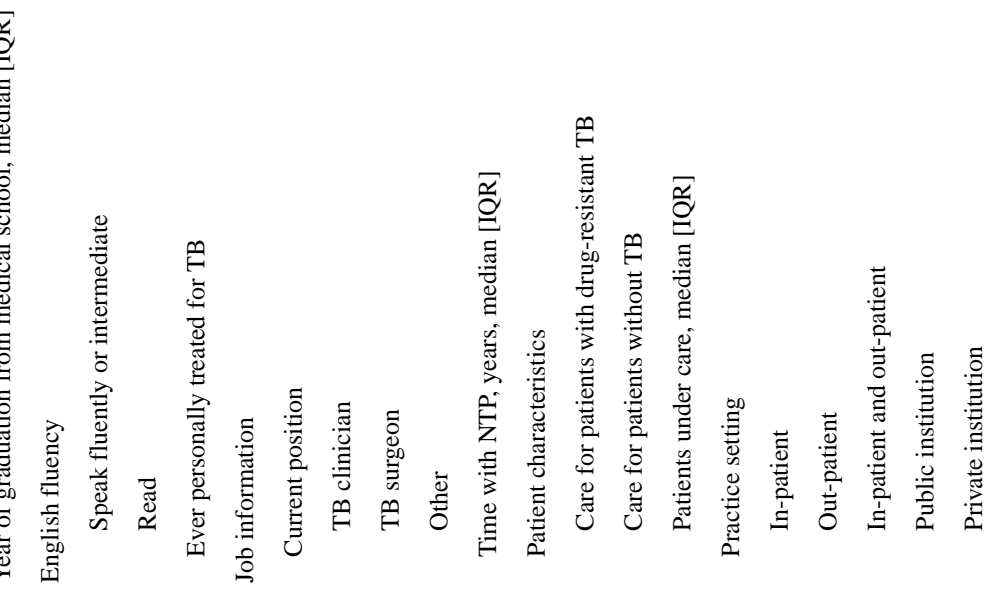




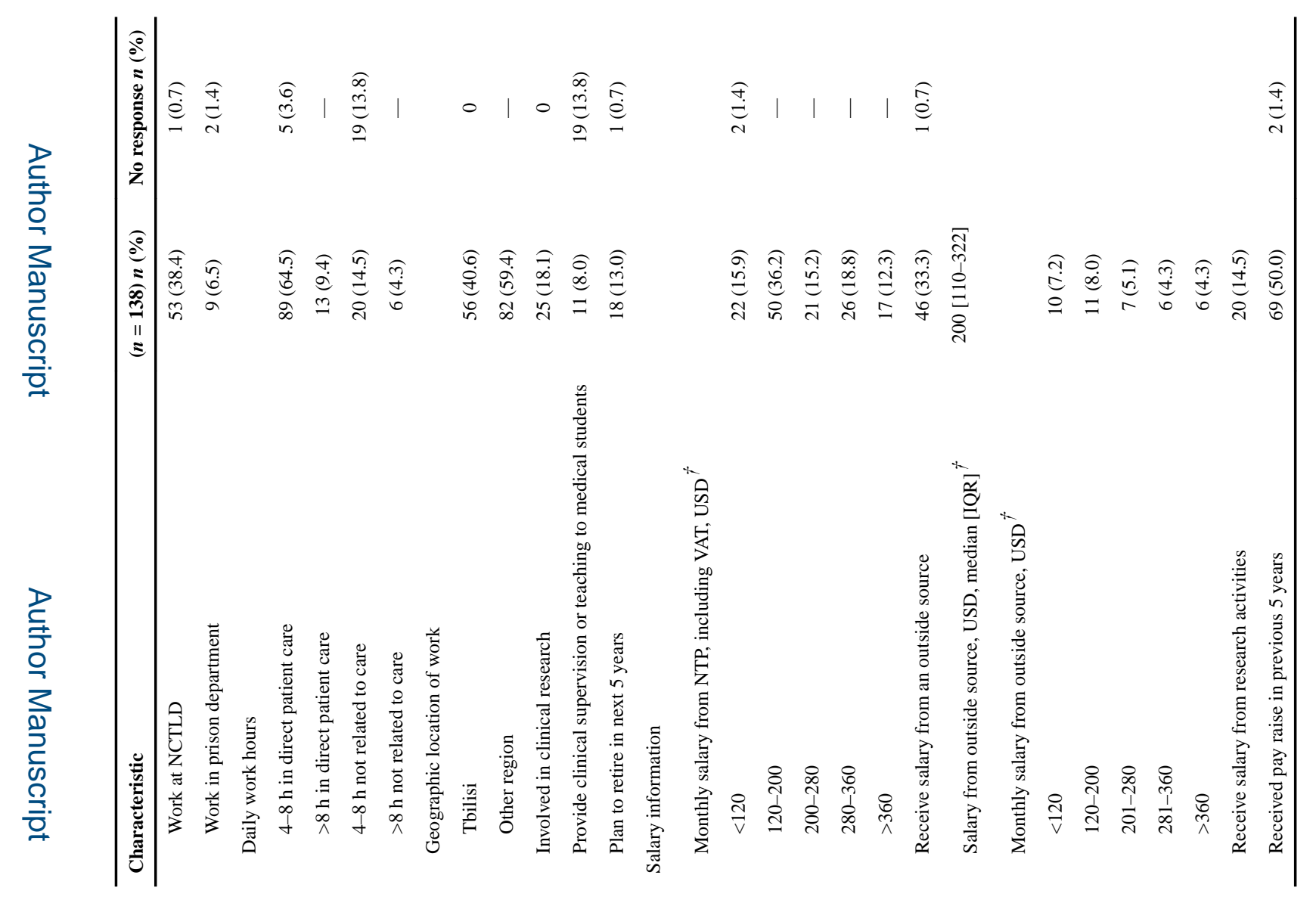

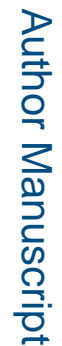

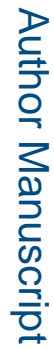




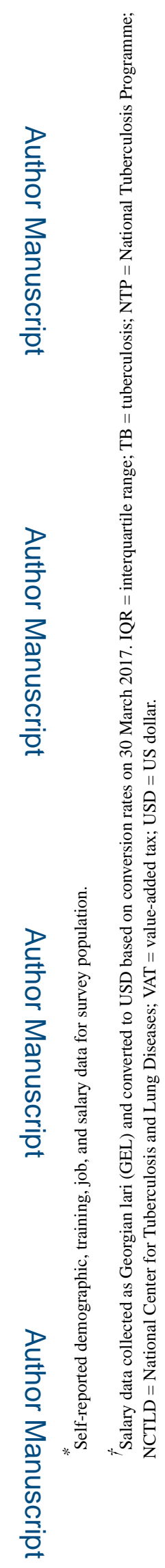

Int J Tuberc Lung Dis. Author manuscript; available in PMC 2019 May 01. 


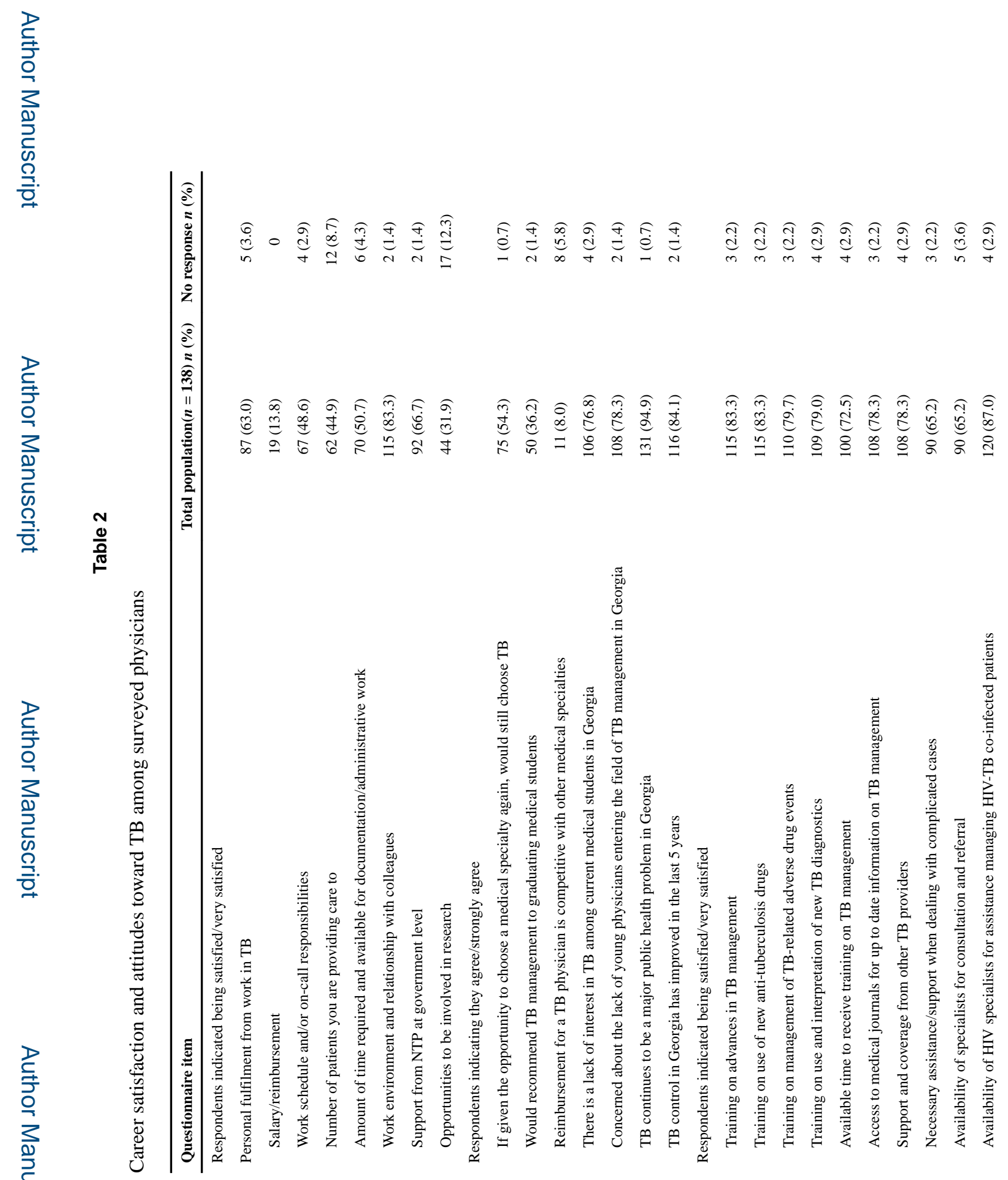

Int J Tuberc Lung Dis. Author manuscript; available in PMC 2019 May 01. 


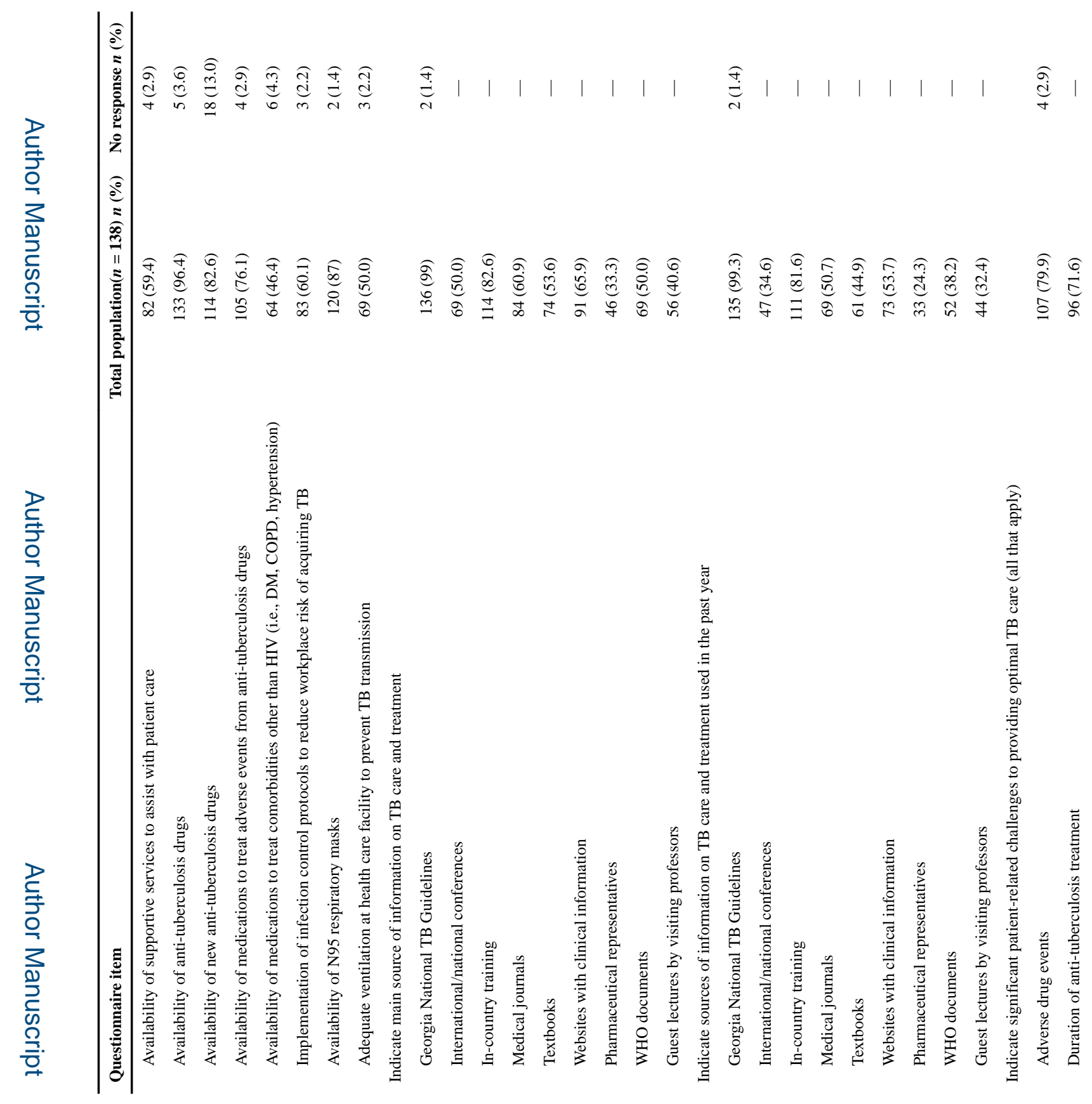

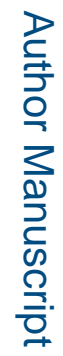

Int J Tuberc Lung Dis. Author manuscript; available in PMC 2019 May 01. 


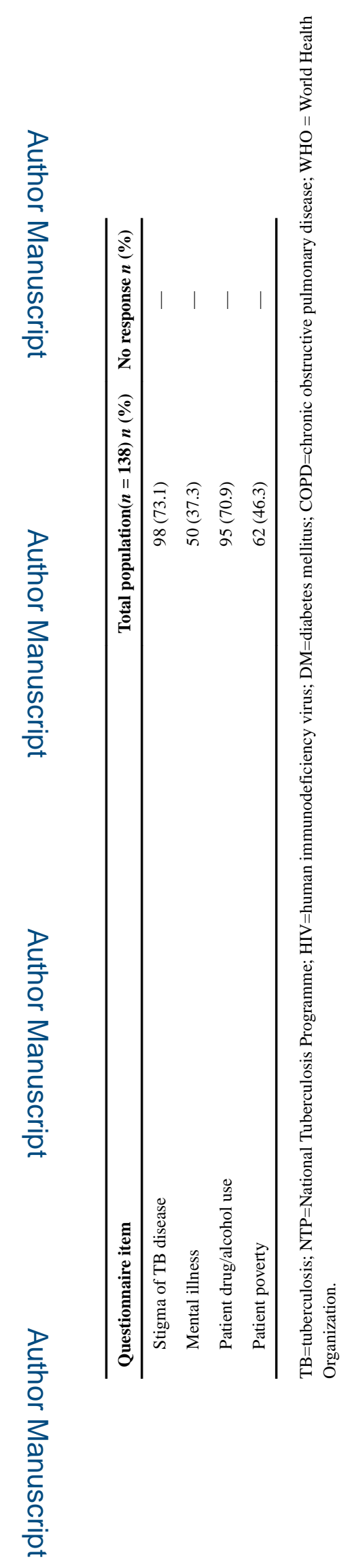

Int J Tuberc Lung Dis. Author manuscript; available in PMC 2019 May 01. 


\section{Table 3}

Contingency table of physicians' self-reported fulfilment from work in TB and willingness to recommend TB management to medical students or choose TB management themselves again*

\begin{tabular}{lrrr}
\hline Personal fulfilment from work in TB & Yes & No & Total \\
\hline Would recommend the field of TB to graduating medical students & $\chi^{2}=17.74, P<0.001$ \\
Yes & 43 & 7 & 50 \\
No & 44 & 44 & 88 \\
Total & 87 & 51 & 138 \\
If you had an opportunity to choose your medical specialty again, you would still choose the field of TB & $\chi^{2}=20.27, P<0.001$ \\
Yes & 60 & 15 & 75 \\
No & 27 & 36 & 63 \\
Total & 87 & 51 & 138 \\
\hline
\end{tabular}

* Respondents categorised as 'yes' for personal fulfilment from work in TB if indicated 'satisfied' or 'very satisfied' and 'yes' for willingness to recommend the field to medical students or choose the medical specialty again if indicated 'agree' or 'strongly agree', otherwise categorised as 'No'. TB = tuberculosis. 